УДК 553.48:549.32/.33

ЗОЛОТОНОСНЫЕ ОТЛОЖЕНИЯ ПЛЯЖА ЮГО-ЗАПАДНОЙ КАМЧАТКИ

Кунгурова В.Е., Газзаева Е.М.

Научно-исследовательский геотехнологический иентр Дальневосточного отделения Российской академии наук, Петропавловск-Камчатский, е-таil: kunwe@yandex.ru, e_gassaeva@mail.ru

\begin{abstract}
Представлены результаты исследований отложений пляжа, содержащих золото, на участке между устьями рек Большая и Митога юго-западного побережья Камчатки. Уточнены имеющиеся и получены новые данные по концентрациям полезного компонента в отложениях пляжа в зависимости от литодинамической активности берегов. Дана характеристика общей золотоносности пляжевых титаномагнетитовых отложений. С течением времени изменяются параметры шлиховых ореолов золота, в том числе их контуры, содержания металла, но места их расположения на участках верхней береговой зоны, в отложениях пляжа, остаются постоянными. Это свидетельствует о непрерывном поступлении золотоносного материала из промежуточных коллекторов, представленных образованиями различного возраста и генезиса, за счет перемыва которых они и образуются. Несмотря на относительно высокую обогащенность золотом пляжей шириной до 30 м, наиболее благоприятными для обнаружения значительных ресурсов золота в прибрежно-морских отложениях являются приклифовые зоны абразионно-аккумулятивных пляжей шириной 30-70 м, где в ряде проб как в поверхностном слое отложений, так и в основании разреза отмечается содержание Аu до нескольких г/м³. На смежных с золотоносным пляжем участках подводного склона также встречены повышенные концентрации золота (от $50 \mathrm{mr} / \mathrm{M}^{3}$ до первых $\Gamma / \mathrm{M}^{3}$ ). Помимо исследованного участка пляжа, шлиховой ореол золота прослеживается прерывистой полосой вдоль берега на протяжении более 250 км на север, что свидетельствует о значительной перспективе выявления промышленных россыпей золота. Дальнейшие исследования могут быть увенчаны обнаружением россыпей золота как на пляже и мелководном шельфе, так и в пределах континентальной части Западной Камчатки.
\end{abstract}

Ключевые слова: юго-западная Камчатка, золотоносность, прибрежно-морские россыпи, отложения пляжа

\title{
GOLD MINERALIZATION DEPOSITS OF THE BEACH OF SOUTH-WESTERN KAMCHATKA
}

\section{Kngurova V.Ye., Gazzaeva E.M.}

Research Geotechnological Center, Far Eastern Branch of Russian Academy of Sciences, Petropavlovsk-Kamchatsky,e-mail:kunwe@yandex.ru,e_gassaeva@mail.ru

The results of studies of gold-bearing beach deposits on the plot between the Bolshaya and Mitoga rivers mouths of the Kamchatka South-West coast are presented. The existing and new data on the useful component concentrations in the beach sediments depending on the shores lithodynamic activity are clarified. The characteristic of the beach formations total gold mineralization is given. Over time, the parameters of the gold halos - their contours and metal content - are changed, but their locations on the upper coastal zone in the beach sediments, are constant. This indicates the gold mineralization material continuous flow from intermediate reservoirs represented by formations of various ages and genesis. Despite relatively high gold enrichment of beaches up to $30 \mathrm{~m}$ wide, the most favorable for the discovery of significant gold resources are near-cliff zones of abrasive-accumulative beaches (30-70 m wide) where a number of samples both in the surface layer of sediments and at the base of the section contains Au (up to several $\mathrm{g} / \mathrm{m}^{3}$ ). Also increased concentrations of gold are found in the areas of the underwater slope adjacent to the gold-bearing beach (from $50 \mathrm{mg} / \mathrm{m}^{3}$ to the $1 \mathrm{~g} / \mathrm{m}^{3}$ ). Besides the investigated section of the beach, a gold halo lines along the coast for more than $250 \mathrm{~km}$ to the north, which indicates a significant prospect of identifying industrial gold placers. Further research can result in the detection of industrial gold placers not only in the beach and shallow shelf, but also within the continental part of Western Kamchatka.

Keywords: South-West Kamchatka gold mineralization, coastal-marine placers, beach deposits

Практически во всех поясах и зонах побережий и мелководного шельфа мирового океана проявлена россыпная золотоносность [1-3]. Однако промышленные скопления металла ограничены несколькими районами с характерными геолого-историческими обстановками. На территории России во второй половине XX в. в результате проведенных научно-исследовательских и геолого-разведочных работ были выделены районы с перспективной золотоносностью прибрежно-морских россыпей - это Южное Приморье, Западное Приохотье, Чукотка [4, 5]. Недостаточно изученным остается западное побережье полуострова
Камчатка, представляющее собой специфическую провинцию небольших современных россыпей золота прибрежно-морского генезиса.

Исследования направлены на изучение золотоносных образований верхней береговой зоны (пляжа) юго-западной части Камчатки с целью выявления перспектив обнаружения промышленно значимых прибрежно-морских россыпей золота. Современные морские пляжевые образования представлены чередующимися прослоями разнозернистых песков, гравия, гальки. От мыса Левашова и далее на север в отложениях пляжа прослеживается ореол рассе- 
яния золота общей протяженностью более 250 км, шириной до 40 м [6, 7]. В мелководной зоне шельфа в отложениях подводных террас также выделены золотоносные участки. Золотоносность пляжей находится в прямой зависимости от гидродинамической обстановки. Рельеф береговой зоны имеет довольно сложное строение, хотя береговая линия представляет собой почти прямой отрезок дуги, пологовыпуклый к западу. Границей раздела между береговой и морской частью является гребень, образованный под воздействием волновой абразии на уже сложившиеся пляжи. В районе исследований берег является абразионно-аккумулятивным образованием. Аккумулятивные участки, как правило, зажаты между абразионными, преобладающими в пределах исследуемой береговой линии. Разнообразие пляжей определяется, прежде всего, различной устойчивостью слагающих их отложений к воздействию штормов. Происходит постоянное динамическое взаимодействие с отложениями прибрежной зоны суши и подводного берегового склона.

\section{Материалы и методы исследования}

Объектом изучения являются золотоносные отложения пляжа на участке побережья от мыса Левашова до устья реки Митога (рис. 1). Продолжены исследования, проведенные в 1966-1976 гг. сотрудниками Камчатского и Приморского территориальных управлений [6], а в 1998, 2015, 2019 гг. - Научно-исследовательским геотехнологическим центром Дальневосточного отделения Российской академии наук (НИГТЦ ДВО РАН) [7-9]. В 2019 г. были выполнены поисковые маршруты с геоморфологическими наблюдениями, осуществлено шлиховое опробование, уточнены имеющиеся и получены новые данные по концентрациям полезного компонента в отложениях пляжа в зависимости от литодинамической активности берегов.

С целью изучения ореолов золота на современном пляже из поверхностного слоя отложений и по разрезу на глубину до 1,0 м были отобраны и обработаны 45 проб массой от 0,4 до 25 кг, большинство из которых (34 шт.) взяты преимущественно с поверхности пляжа, у основания клифа, где наиболее часто обнаруживаются бросающиеся в глаза поля сине-черного песка в виде полос, а также у основания штормовых валов и вблизи уреза воды. Материал проб в большинстве случаев представляет собой естественный шлих черного цвета, состоящий из тяжелых минералов. Помимо золота, здесь присутствуют значительные количества титаномагнетита, ильменита, граната.

Проведены гранулометрический, минералогический анализы. Изучалась фракция 0,1-0,5 мм (наиболее продуктивная с точки зрения золотоносности), выделенная в процессе гранулометрического анализа проб, которая затем разделялась на фракции по магнитным свойствам. С использованием микроскопа МБС-10 отобрано золото, подсчитано его количество (в мг/ $\mathrm{M}^{3}$ ) относительно изначально опробуемого материала. Полный минералогический анализ проб проведен на рентгеновском дифрактометре Rigaku Ultima IV методом рентгеновской спектроскопии [10]. Съемка дифрактограммы порошка проб проводилась с использованием D/tex детектора в диапазоне углов $2 \Theta 10$ 100 град со скоростью 1,0 град/мин. Идентификация кристаллических фаз в пробе проведена по полученным параметрам элементарных ячеек, межплоскостных расстояний и относительным интенсивностям соответствующих линий на рентгенограммах.

Проба золота определена атомно-абсорбционным анализом, элементы-примеси в золоте определены полуколичественным спектральным анализом методом испарения из канала электрода. Чувствительность анализа составляет (в $\left.\mathrm{n} \times 10^{-4} \%\right): \mathrm{Pb}-5, \mathrm{Ag}-100$, $\mathrm{Cu}-5, \mathrm{Zn}-10, \mathrm{Co}-0,5, \mathrm{Hg}-1000, \mathrm{Fe}-0,01$.

\section{Результаты исследований и их обсуждение}

Современные пляжевые отложения слагают полосу шириной 20-120 м, узкой частью примыкающую к береговому обрыву (высотой до 20 м, периодически подвергающемуся абразии) и расширяющуюся в местах, где пляжи в виде берегового бара надвинуты на низменные прибрежные участки суши (на поверхность первой морской террасы и лагун). На пляже повсеместно развиты естественные ореолы гранат-магнетитового шлиха. Их относительно высокая концентрация не ограничивалась тонким (до 0,1 м) поверхностным слоем, а распространялась в некоторых участках на глубину до 1 м в виде маломощных слойков по разрезу. Поперечный профиль пляжа асимметричен. Материал, слагающий пляжи, галечно-гравийно-песчаный, тонкослоистый, с примесью детрита ракуши. В целом по разрезу выделяются линзы и слои, сложенные какой-либо одной преобладающей фракцией. Характерны хорошая сортировка, окатанность и отмытость материала. 


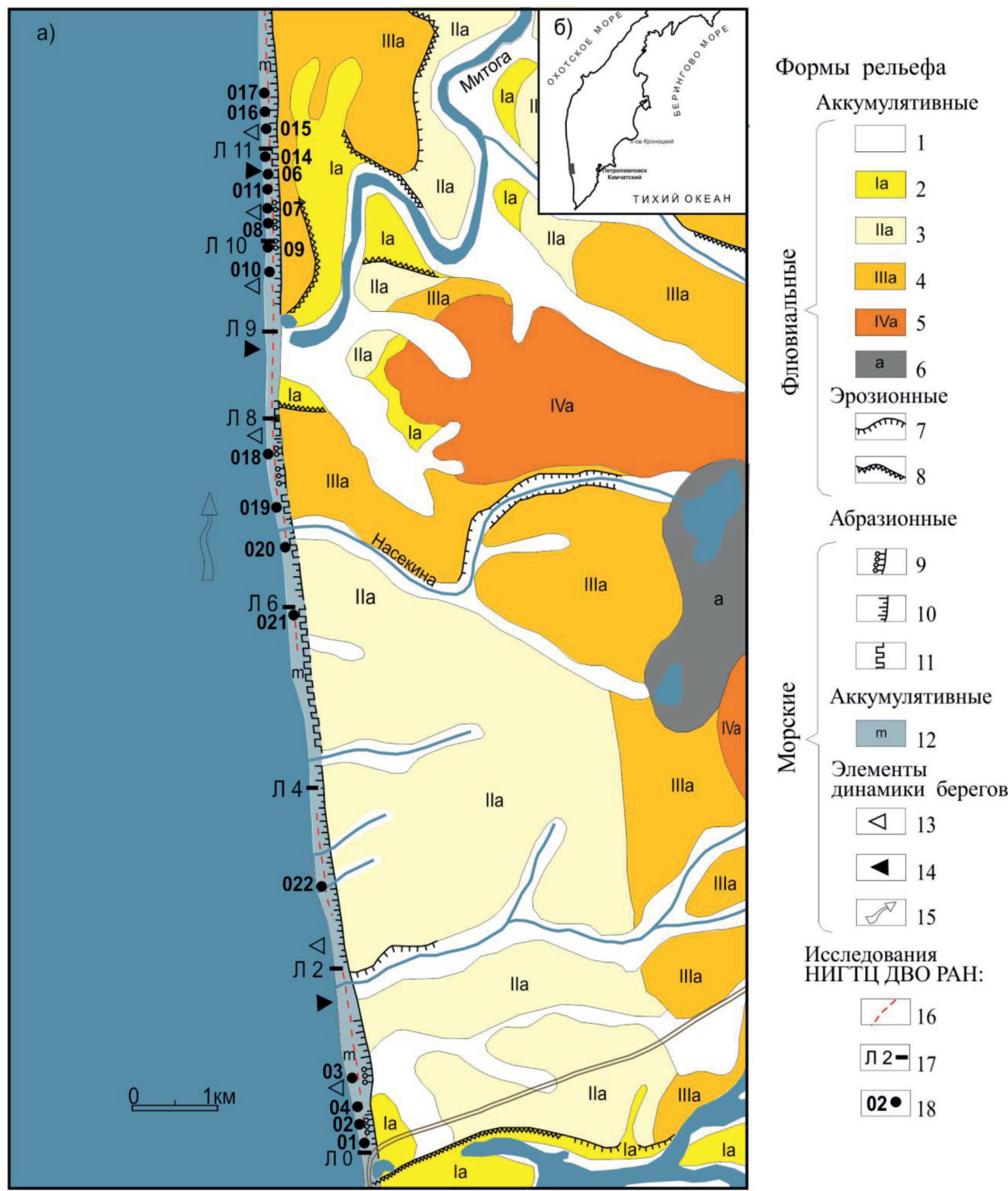

Рис. 1. Схематическая геолого-геоморфологическая схема района исследований (а) (с использованием в качестве основы материалов [6]), обзорная карта (б)

Условные обозначения: 1 - уровень высокой поймы; 2 - уровень 1-й надпойменной террасы высотой 3-6 м; эрозионно-аккумулятивные уровни: 3 - 2-й надпойменной террасы высотой 12-14 м, 4-3-й надпойменной террасы высотой 20-25 м, 5-4-й надпойменной террасы высотой 30-36 м; 6 - нерасчлененный комплекс древнечетвертичных аллювиальных террас высотой до 60 м; 7 - деятельный эрозионный уступ, 8 - отмерший, 9 - полуактивный клиф, подвергающийся абразии во время сигизийных приливов, 10 - полуактивный клиф, подвергающийся абразии только во время штормов, 11 - полуактивный клиф, имеющий узкую полоску марша и подвергающийся абразии только во время штормов; 12 - аккумулятивные формы современной береговой зоны;

13 - поступление обломочного материала на береговой подводный склон за счет абразии;

14 - поступление обломочного материала с подводного склона на верхнюю зону пляжа;

15 - предполагаемое направление движения вдольберегового потока наносов; 16 - участки повышенной концентрации естественного гранат-магнетитового шлиха; 17 - линии, по которым опробованы отложения пляжа в 1998 и 2015 гг; 18 - точки наблюдений и отбора проб в 2019 г.

В пределах исследуемого участка побережья от мыса Левашова до устья реки Митога выделяются пляжи неполного профиля на участках развития абразионных бе- регов (рис. 2, 3а, б, в) и полного (рис. 3г), где преобладают процессы аккумуляции и развиты приустьевые косы, пересыпи, береговые бары. 


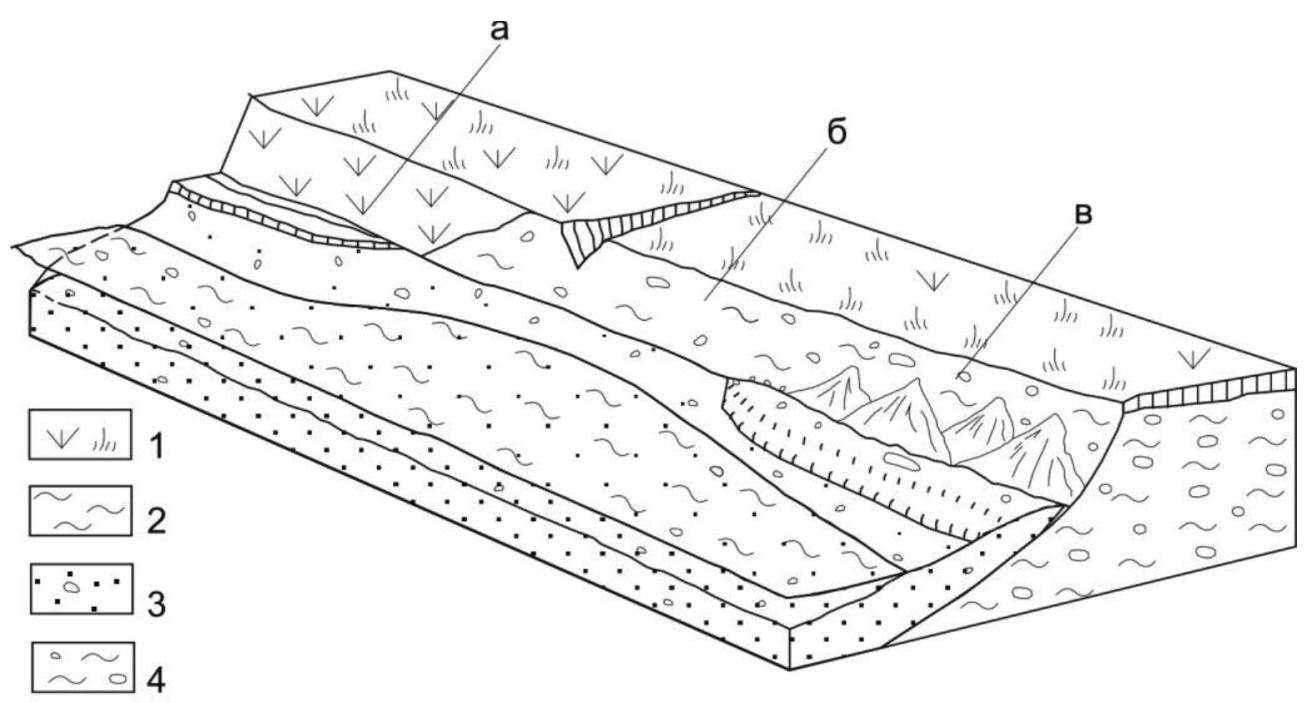

Рис. 2. Схематическая зарисовка абразионных берегов с пляжами неполного профиля: с маршевыли зонами, заростими растительностью, ранее абрадированньии, разрушается лишь во время очень сильных штормов, ширина пляжа 50-70 м (а); абрадируемыц морем во время действия как штормов, так и приливов, ширина пляжа 20-30 м (б); с эпизодической абразией во время штормов, иирина пляжа 30-50 м

Условные обозначения: 1 - растительный покров, 2 - глинистые образования, 3 - песчано-галечные отложения, 4 - гравийно-галечные образования с глиной

В целом по направлению от моря к береговым обрывам степень сортировки отложений на этих пляжей возрастает, что обусловлено сменой гидродинамических условий их накопления. Во фронтальной части пляжа они представлены крупнопесчано-гравийно-галечным материалом, в тыловой приклифовой зоне - средне-мелкопесчанистыми образованиями.

Пляжи неполного профиля - очень динамичные образования (рис. За, б, в). К основанию клифа прислонен наложенный на бенч пляж. Клиф крутизной 40$80^{\circ}$ подвергается периодической абразии во время приливов и штормов. Здесь широко развиты обвально-осыпные процессы, приводящие к нарушению устойчивости склона и обрушению массы рыхлой породы на пляж с ее последующим размывом. Затем вследствие грануло-минералогической дифференциации формируются естественные концентрации тяжелых минералов, а легкие фракции выносятся на подводный береговой склон. Условия россыпеобразования на пляже находятся в прямой зависимости от гидродинамической обстановки и объема золотоносного переработанного материала. Мощность отложений и содержание тяжелых минералов, в том числе золота, колеблются в широких пределах.
По литодинамической активности выделены пляжи неполного профиля нескольких типов [6-8].

Пляжи шириной до 30 м, мощностью до 1,5 м, его отложения подвергнуты наиболее существенной волновой переработке, испытывают дефицит наносов. Они встречены в т.н. 02, 03, 07, 09, 018 (рис. 3a). По сравнению с соседними участками абразионного берега здесь отмечается относительная обогащенность пляжевых отложений тяжелыми минералами. Визуально это видно в наличии ярко выраженных синевато-черных ореолов естественного гранатмагнетитового шлиха, которые формируются (рис. 4) у основания клифа (ширина 2-6 м, длина струй 130-150 м, мощность от 1 до 6 см, содержание золота колеблется от $115 \mathrm{мг} / \mathrm{M}^{3}$ до $420 \mathrm{Mг} / \mathrm{M}^{3}$ (пр. 09/2, рис. 1,3)). В образованиях пляжа средний размер минералов тяжелой фракции составляет 0,14 мм. По результатам исследований, проведенных НИГТЦ ДВО РАН в 1998 и 2015 гг., в отложениях расположенных рядом причлененных пляжей (в горных выработках по линиям Л-0, Л-10, рис. 1) золото содержится в количестве $202 \mathrm{M \Gamma} / \mathrm{M}^{3}$ и $1050 \mathrm{M \Gamma} / \mathrm{M}^{3}$ соответственно, а среднее содержание золота по результатам поисково-разведочных работ 1974-1978 гг. [6] составляет $289 \mathrm{мг} / \mathrm{M}^{3}$. 


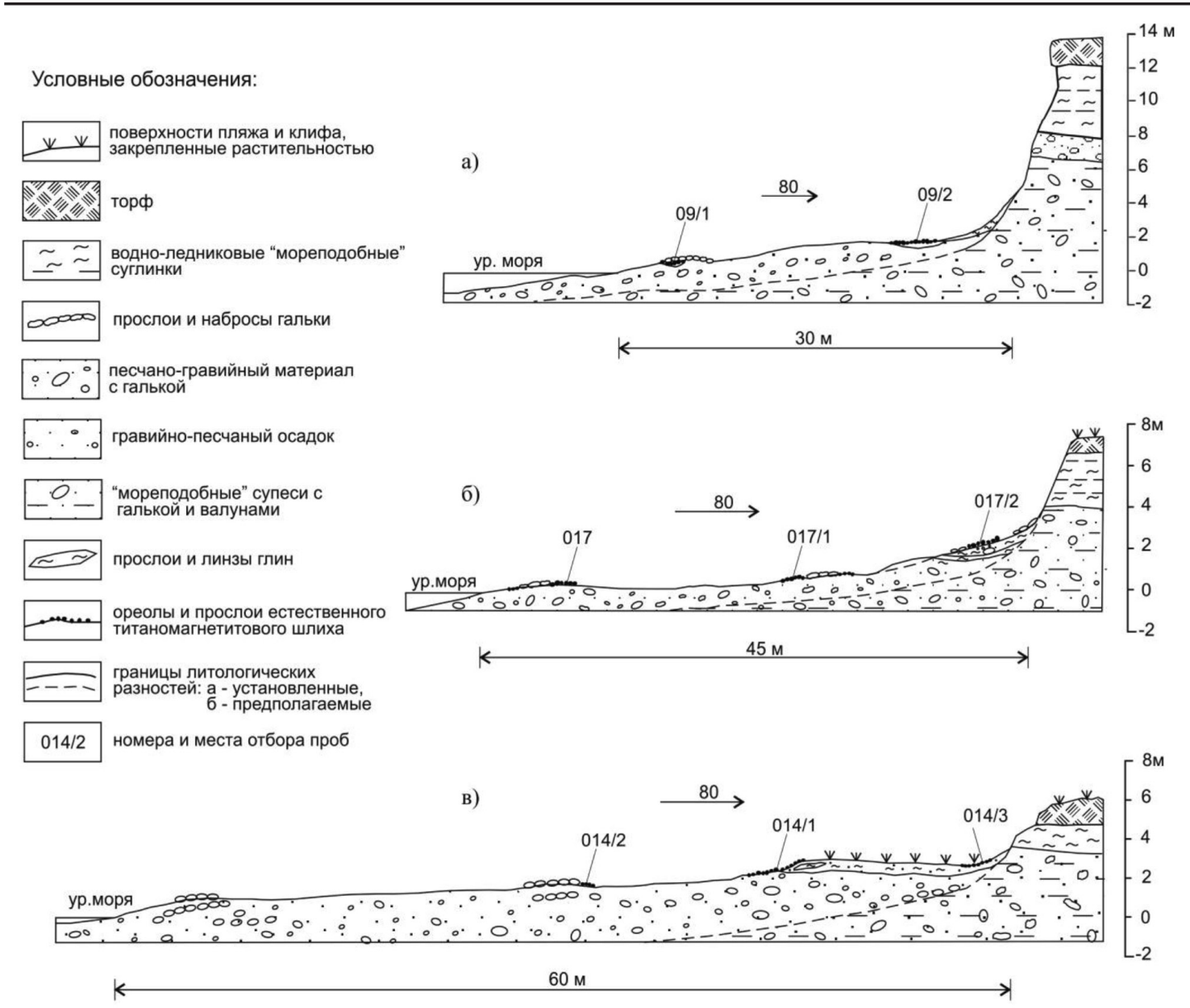

г)

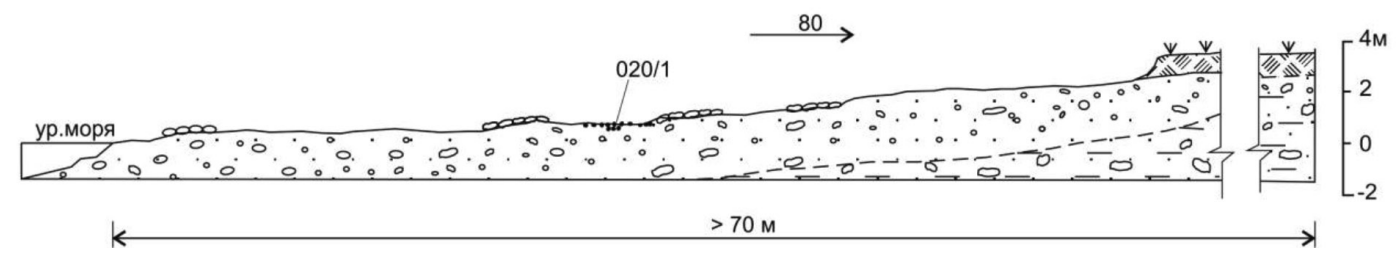

Рис. 3. Типичные схематические геологические разрезы пляжей неполного профиля: причлененные (а), прислоненные (б), с маршевыми зонами (в); и полного профиля (г)

При определенных благоприятных условиях в тыловой зоне могут сформироваться серии прослоев естественного шлиха, что наблюдалось нами в т.н. 03. Самый нижний прослой шлиха образовался, вероятно, при сильном волнении, когда пляжевые отложения были оттянуты на подводный склон, а затем абрадированы бенч и клиф, из золотоносного материала которых при ослаблении волнения был сформирован продуктивный прослой на глубине $30 \mathrm{~cm}$, мощностью

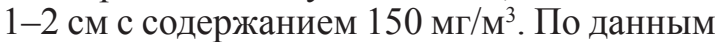
проведенных ранее поисковых работ [6] в аналогичных геоморфологических условиях, севернее в 100 м от т.н. 017, у основании клифа, в шурфе глубиной до 1,0 м были опробованы 2 прослоя естественного шлиха мощностью до 5 см, которые содержали $2095 \mathrm{Mг} / \mathrm{M}^{3}$ и $1525 \mathrm{мг} / \mathrm{M}^{3}$ золота.

При сильном волнении, когда зона абразии включает клиф, бенч и выходы континентальных отложений подводного склона, возможно формирование золотоносного естественного шлиха, залегающего на бенче и в основании клифа. Волновая переработка отложений на таких узких абразионных 


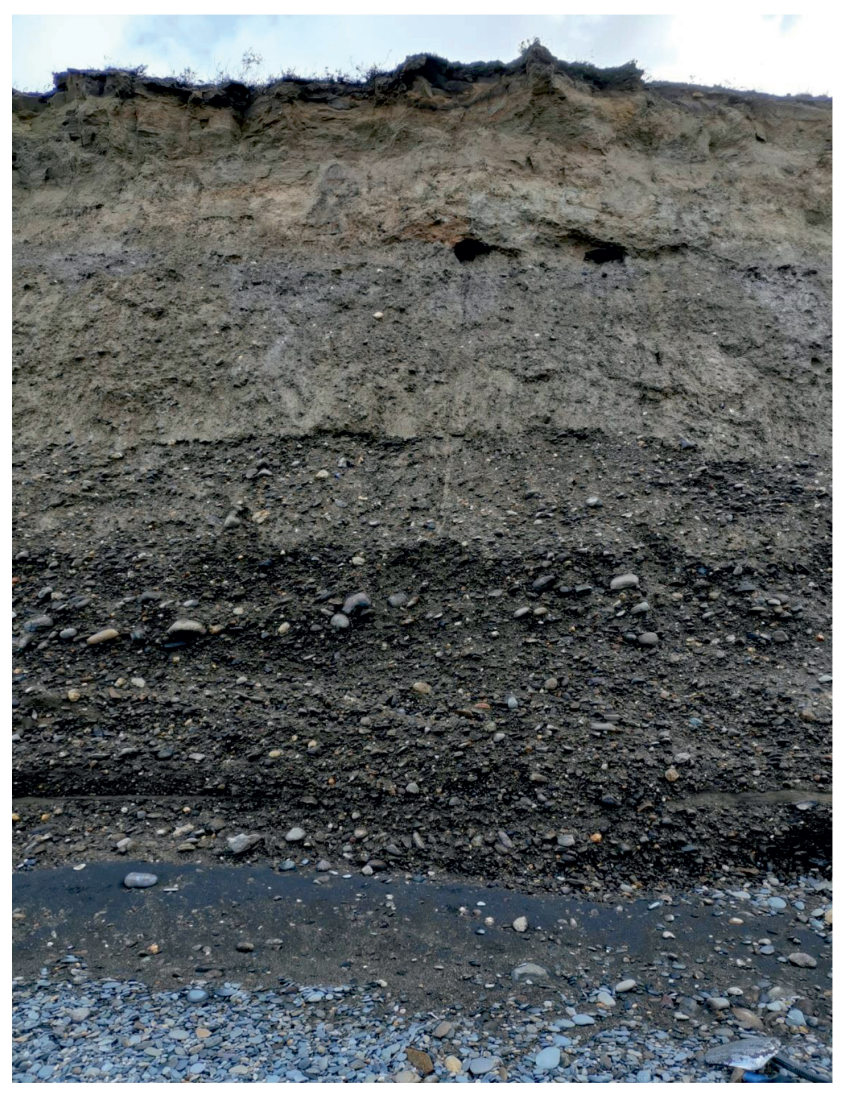

Рис. 4. Золотоносный гранат-магнетитовый естественный илих (т.н. 03) у основания берегового обрыва. Пляж шириной до 30 м

пляжах идет очень интенсивно, их относительная обогащенность золотом высокая. Но формирование промышленных россыпей вряд ли возможно в связи с размываемостью их штормами. В период 19731977 гг. [6] были проведены наблюдения за разрушением такого типа пляжей на югозападной Камчатке. Скорость отступления берега за год составила от 0,85 до 6,6 м.

Пляжи шириной 30-50 м занимают значительную по протяженности часть берега, имеют меньшую вогнутость тыловой зоны; их поверхность осложнена штормовыми валами высотой 0,3-0,7 м. Прослежены в т.н. 05, 06, 010, 013, 016, 017 (рис. 5, 6, рис. 3б).

Пляжи меньше подвержены волновой переработке, в тыловой части менее вогнуты, состоят из небольших участков намыва и размыва (выпуклых и вогнутых). Скорость отступания берега составляет в среднем 0,35 м/год [6]. В поперечном профиле пляжа в его поверхностном слое наблюдается до трех зон естественного шлиха. Все ореолы концентраций тяжелых минералов относятся к фракции мелкозернистых песков. В местах, где происходит размыв, отмечается наиболее интенсивное шлихование пляжевых наносов. К этим участкам дефицита наносов и приурочены повышенные содержания золота в каждой из зон концентраций естественного шлиха: вблизи уреза воды отмечены вытянутые «язычки» длиной 10-50 см, шириной 2-5 см, содержание золота от $5 \mathrm{мг} / \mathrm{M}^{3}$ до $15 \mathrm{мг} / \mathrm{M}^{3}$; у основания штормового вала - полосы, пятна длиной 1-5 м, шириной 0,3-1 м, содержание золота составля-

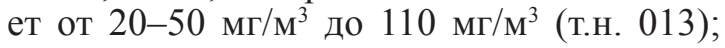
у клифа встречена наиболее обогащенная зона - прерывистые полосы средней шириной 2-3 м, длиной в десятки и сотни метров с высокой концентрацией в поверхност-

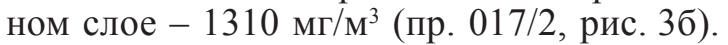
В аналогичной геоморфологической обстановке, у клифа, в поверхностном слое ранее [6] рядом с т.н. 016 были обнаружены более высокие концентрации благородного металла - 2695 мг/м³ , а в подошве пляжа

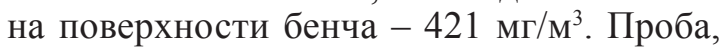
отобранная нами из отложений пляжа такого же типа по линии Л-11 (рис. 1), содер-

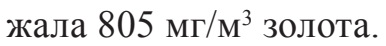




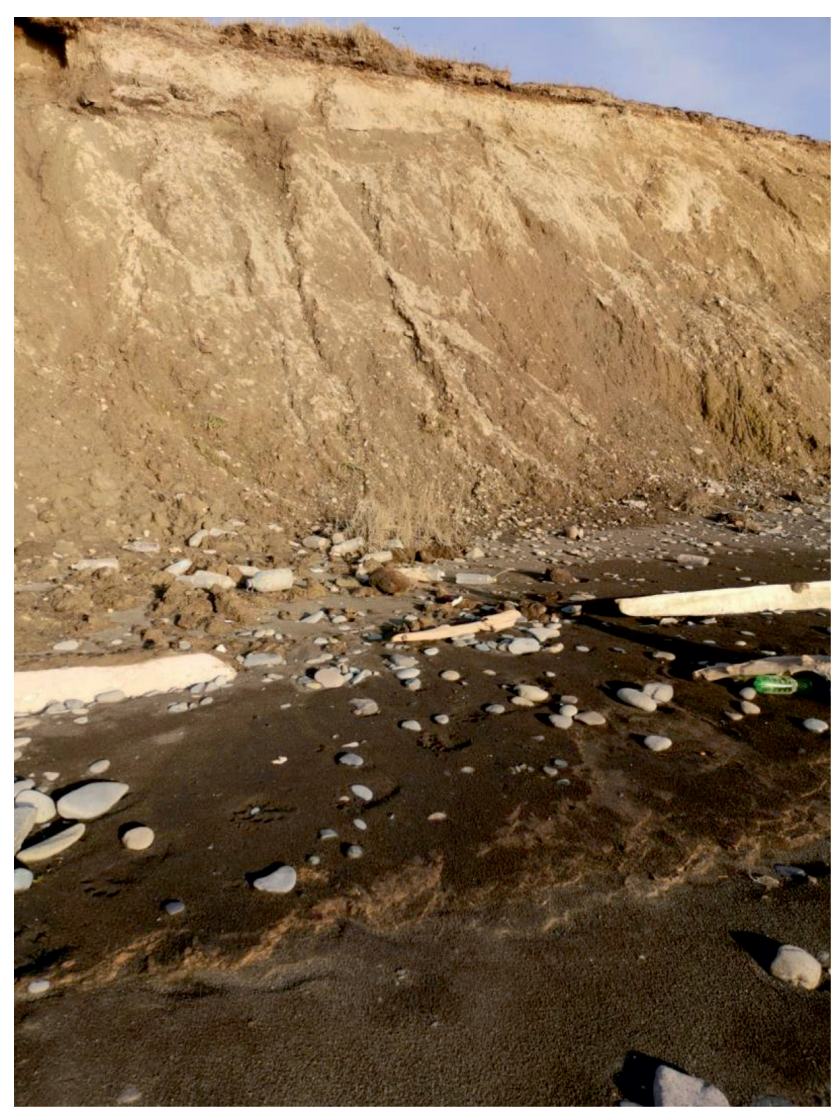

Рис. 5. Естественный гранат-магнетитовый илих на глинистой «подложке» у основания клифа на пляже шириной 30-50 м (т.н. 017)

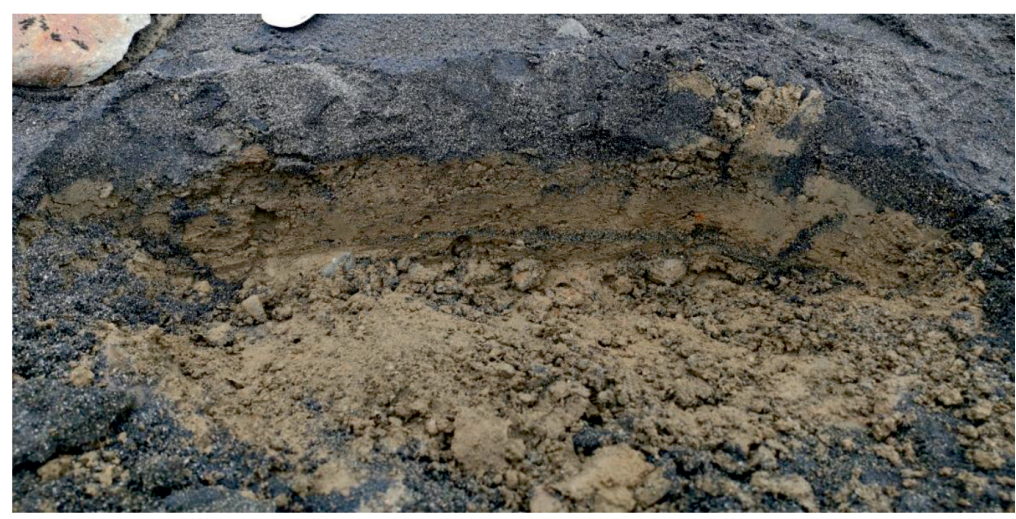

Рис. 6. На поверхности пляжа - гранат-магнетитовый естественный илих мощностью до 10 см на песчано-глинистой основе; в нижней части разреза - прослой естественного илиха с изменяющейся мощчностью от 0,5 до 2 см (т.н. 017)

Пляжи шириной 50-70 м подвержены наименьшей волновой переработке, испытывают гидродинамическое воздействие лишь при очень сильных штормах. Клифы, к которым они прислонены, имеют крутизну $30-40^{\circ}$, абрадированы лишь у их оснований. Склон нередко бывает заросшим. Обратный прибойный поток слабый. Скорость отступления бровки клифа $-0,03$ м за 2 года [6]. Это пляжи абразионно-аккумулятивного типа (т.н. $014,015,019,022$, рис. 7 , рис. 3в). Шлиховые ореолы на поверхности пляжа выражены слабее, концентрация тяжелых минералов в общей массе отложений 
меньше, содержание золота - до 180 мг/ $\mathrm{M}^{3}$ (пр. 014/2). Эти участки нередко осложнены приклифовыми аккумулятивными бермами и перспективны для образования многоярусных россыпей. В тыловой зоне, чаще у основания клифа, прослеживаются по разрезу мощностью 1,0 м захороненные серии слойков (2-7) естественного гранат-магнетитового шлиха мощностью от 1 до $10 \mathrm{~cm}$, с содержанием золота от $15 \mathrm{мг} / \mathrm{M}^{3}$ до $75 \mathrm{Mг} / \mathrm{M}^{3}$. Наиболее золотоносный пласт встречен

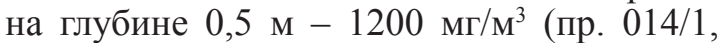
рис. 3в), а по данным проведенных ранее поисковых работ [6] на пляжах такого типа $-3240 \mathrm{мг} / \mathrm{M}^{3}$.

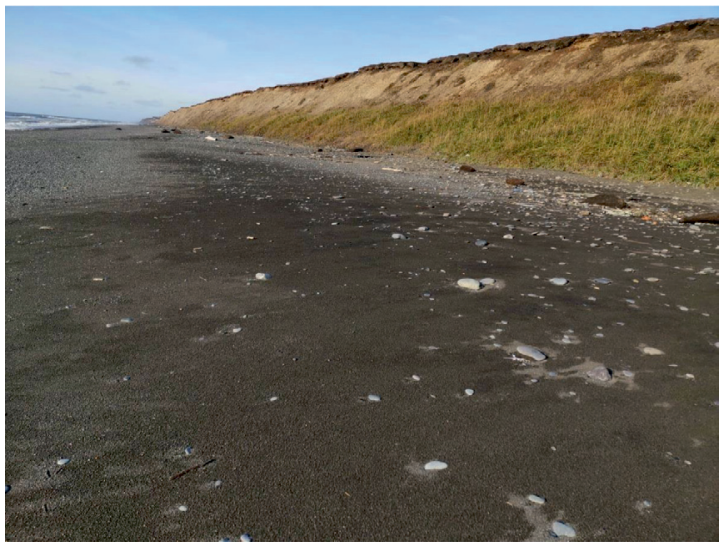

Рис. 7. Типичный абразионно-аккумулятивный пляж шириной 50-70 м (т.н. 014)

В тыловой зоне таких пляжей нередко находится узкая (до 10 м) закрепленная растительностью маршевая полоса. На поверхности глинистого плаща в пределах марша откладывается струйчатопятнистый ореол гранат-магнетитового шлиха. В толще марша устанавливаются несколько ритмов, состоящих из чередующихся глинистых прослоев, покрытых естественным шлихом, и песчано-гравийных слоев (рис. 8). По нашим данным, в отложениях марша у основания клифа содержание золота колеблется от $20 \mathrm{Mг} / \mathrm{M}^{3}$ до $200 \mathrm{мг} / \mathrm{M}^{3}$. Естественно отшлихованный материал, содержащий полезные компоненты, иногда забрасывается штормовой волной на поверхность марша, что наблюдалось в т.н. 019. Мощность его составила 0,1 м, площадь распространения 1,0 х 0,2 м, содержание золота - $25 \mathrm{мг} / \mathrm{M}^{3}$. В т.н. 022 за бровкой низкого (1-1,5 м) торфяного клифа опробован штормовой наброс маломощных (до 0,3 м) пляже- вых отложений, представляющих собой естественный шлих, плотиком при этом является торфяник. Концентрация золота составила $205 \mathrm{мг} / \mathrm{M}^{3}$. Южнее этой точки наблюдения, в 0,9-1 км от нее, ранее [6] были зафиксированы штормовые набросы продуктивного материала (мощностью до 0,5 м) в подобных геоморфологических условиях. Максимальные содержания 3олота составляли здесь 326 мг/. ${ }^{3}$.

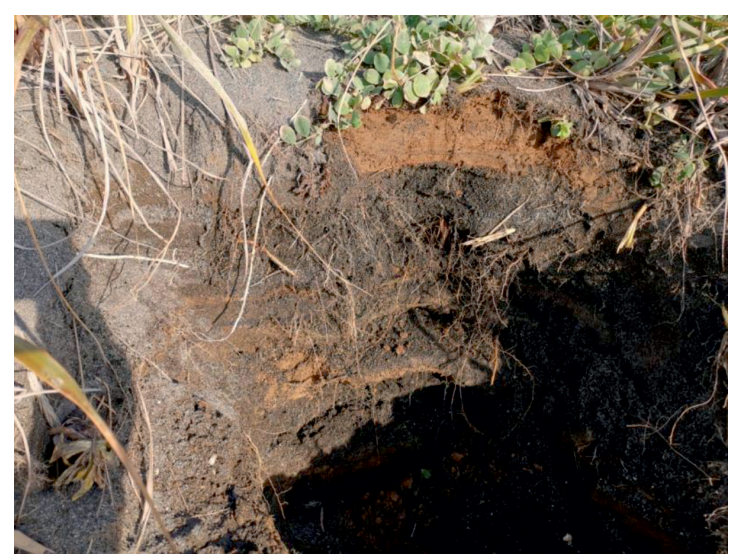

Рис. 8. Разрез пляжа в маршевой зоне, у основания марша, покрытого растительностью. Переслаивание средне-мелкозернистого песка (темное) пироксен-гранат-магнетитового состава, содержашего золото, с песчаноглинистылми отложениями (рыжее) (т.н. 014). Мошность верхнего глинистого слоя - 7 см

Пляжи полного профиля в районе исследования развиты на аккумулятивных участках берега, характеризуются слоистым строением, мощность отложений (по данным бурения, [6]) более 13 м. Их ширина колеблется в пределах 90-120 м. Для них характерны продвинутые в прибрежную низменность бары высотой до 1,5 м. Формирование пляжей связано, в основном, с вдольбереговой миграцией отложений, которые образуются в результате разрушения соседних абразионных участков, на которые они опираются, и подводного берегового склона.

Отобраны пробы из пляжевых отложений в районах приустьевой части реки Насекина (т.н. 020, рис. 3г, рис. 9). Здесь к морю выходит эрозионное понижение с несколько более повышенными абсолютными отметками, чем, например, на аккумулятивных отрезках приустьевых кос рек Большая, Митога. Нижняя часть пляжа прислонена к клифу (высотой до 1,0 м) в торфянике. Клиф подвергается незначительной 
абразии. У его основания концентрация золота составила $110 \mathrm{mг} / \mathrm{M}^{3}$. За бровкой клифа на торфянике в виде берегового вала встречен штормовой выброс маломощных (0,1-0,2 м) морских отложений. Содержание золота в них $-20 \mathrm{mг} / \mathrm{M}^{3}$. Наличие золота может быть объяснено либо присутствием находящегося рядом абразионного берега с повышенными концентрациями золота в его отложениях и их дальнейшим вдольбереговым перемещением, либо размывом золотоносных отложений подводного склона [6]. В целом, в аккумулятивных телах рассматриваемого типа содержание золота

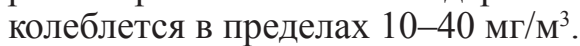

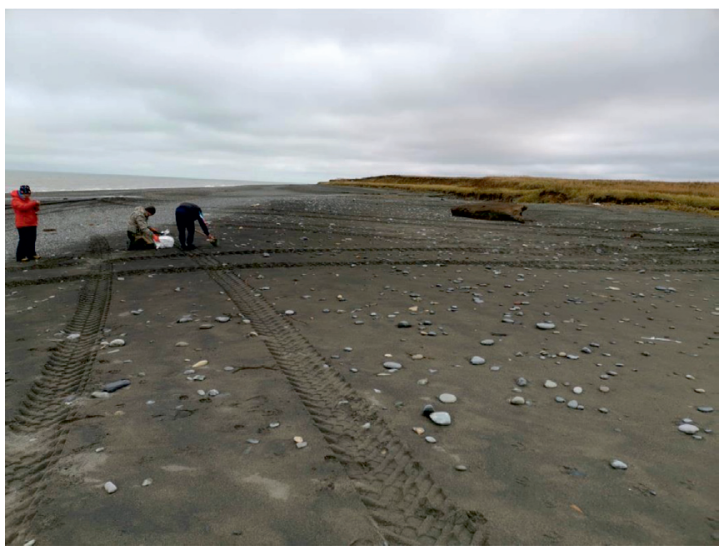

Рис. 9. Пляж полного профиля в приустьевой части р. Насекина. «Размазанные» границь илиховых ореолов (т.н. 020)

Несмотря на то что в отложениях полного профиля содержание золота состав-

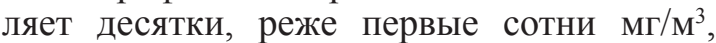
из-за больших объемов горной массы запасы полезных компонентов могут быть значительными. Шлиховые ореолы на этих пляжах не имеют четких границ и несут, в первую очередь, первичную информацию о потенциальной золотоносности отложений подводного склона.

Таким образом, наиболее перспективными для обнаружения промышленных прибрежно-морских россыпей золота является приклифовая зона абразионно-аккумулятивных пляжей шириной 30-70 м, где в ряде проб как в поверхностном слое отложений, так и в основании разреза отме-

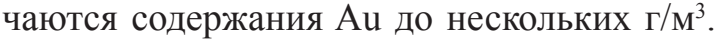
Несмотря на относительно высокую обогащенность золотом пляжей шириной до 30 м, перспективы обнаружения значительных скоплений благородного металла в отложе- ниях пляжа невысоки вследствие размываемости их штормами.

Минеральный состав. Минеральный состав отложений пляжа довольно разнообразен и включает в себя типоморфные минеральные ассоциации магматических, метаморфических, гидротермально-измененных, вулканогенных и изверженных пород. Определен комплекс основных и акцессорных минералов (в легкой и тяжелой фракциях соответственно), слагающих отложения пляжа. Легкая фракция пляжевых отложений представлена кварцем, плагиоклазами, калиевыми полевыми шпатами, слюдисто-глинистые агрегатами, биотитом, мусковитом, обломками горных пород, присутствует ракушечный детрит.

Содержание тяжелой фракции колеблется от 1,0\% до 5,0\% (при отсутствии прослоев естественного шлиха в пляжевых отложениях). В материале поверхностных естественных шлихов количество тяжелых минералов резко возрастает, достигая 50$70 \%$, в единичных пробах $-80 \%$. В тяжелой фракции установлены (от общего веса тяжелой фракции): магнетит (40-55\%), пироксен (20-25\%), ильменит (9-20\%), гранат (10-15\%), ставролит (2-4\%), амфиболы (1-2\%), присутствуют золото, эпидот, цоизит, гематит, мартит, лимонит, лейкоксен, дистен, пирит, барит, андалузит, силлиманит, корунд, брукит, циркон, рутил, анатаз, сфен, апатит, единично - шеелит, хромит, арсенопирит, турмалин, флюорит, топаз.

Краткая характеристика наиболее распространенных минералов, которые наряду с золотом могут являться полезными компонентами, приведена ниже.

Золото встречено как в «свободном» состоянии, так и в сростках с безрудными минералами, чаще всего с кварцем, характеризуется слабой степенью сортировки по крупности и окатанности, различается по цвету, форме, характеру поверхности. Цвет его золотисто-желтый, бледно-желтый, серебристо-желтый, желтый с красноватым оттенком. Форма зерен чешуйчатая, лепешковидная, пластинчатая, с изогнутыми краями, скрученная, комковатая, окатанность в основном хорошая (рис. 10). Поверхность слегка шероховатая, мелкоямчатая, иногда покрыта пленкой окислов - гидроокислов железа. Размер частиц колеблется от $<0,07$ мм до 1,5 мм, толщина пластинчатых и таблитчатых выделений колеблется от 0,02 до 0,15 мм (среднее 0,056 мм), средний вес - 0,015 мг. Основные параметры кривых распределения золота по крупности 
на участке исследований составляют: медиана - 0,30 мм, мода - 0,50 мм, коэффициент асимметрии - 0,60. Проба золота из отложений пляжа колебалась от $800 \%$ до $950 \%$. Спектральным анализом в самородном золоте установлены железо (0,1-0,16\%), ртуть $(0,01-1,0 \%)$, медь $(0,007-0,014 \%)$, мышьяк (0,001-0,01\%); марганец, свинец, кобальт, сурьма в количестве тысячных долей процента, теллур, висмут, никель, олово - в десятитысячных.

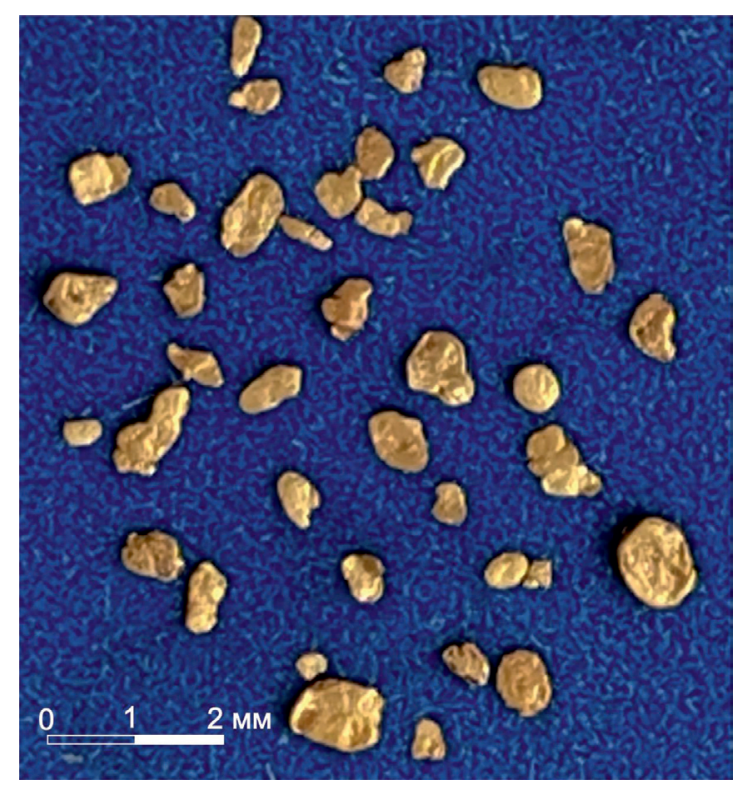

Рис. 10. Золото из отложений пляжа

Магнетит составляет основную часть тяжелой фракции. Это зерна октаэдрической и неправильной формы с шероховатой поверхностью, размером от долей миллиметра до 1,5 мм. В пробах, отобранных с пляжа в пределах гранат-магнетитового естественного шлиха, содержание магнетита колебалось от $10 \kappa г / \mathrm{M}^{3}$ до $80 \kappa г / \mathrm{M}^{3}$. По результатам рентгенофазового анализа на порошковом рентгеновском дифрактометре Rigaku Ultima IV минералы группы магнетита (24-61,4\%) представлены в основном титаномагнетитом $\mathrm{Fe}_{2.75} \mathrm{Ti}_{0.25} \mathrm{O}_{4}$, в незначительном количестве магнезиоферритом $\left(\mathrm{MgFe}_{2}\right) \mathrm{O}_{4}$; встречены кульсонит (ванадиевый магнетит) (Fe, V) ${ }_{3} \mathrm{O}_{4}$, франклинит $\mathrm{ZnFe}_{2} \mathrm{O}_{4}$ и ульвошпинель $(\mathrm{Mg}, \mathrm{Fe})$ $(\mathrm{Cr}, \mathrm{Al}, \mathrm{Fe})_{2} \mathrm{O}_{4}$, являющийся крайним членом серии твердых растворов титаномагнетитов - продуктом распада титанистых титаномагнетитов.

Ильменит присутствует повсеместно в виде уплощенных обломков неправиль- ной формы, угловато-окатанных таблитчатых и ромбоэдрических кристаллов размером от сотых долей до 1 мм. Поверхность их иногда покрыта белесоватыми примазками лейкоксена. По результатам рентгенофазового анализа из минералов группы ильменита идентифицированы ромбоэдрические ильменит (до 7,6\%) $\mathrm{Fe}\left(\mathrm{TiO}_{3}\right.$ ), гейкилит (до 2,8\%) $\left(\mathrm{Mn}_{0.5} \mathrm{Mg}_{0.5}\right) \mathrm{TiO}_{3}$, пирофанит (до $1,1 \%$ ) $\mathrm{Mn}\left(\mathrm{TiO}_{3}\right)$.

Гранаты $\quad(2,7-13,1 \%) \quad$ представлены преимущественно кристаллами ромбододекаэдрической, тетрагон-триоктаэдрической формы, их обломками. Встречено несколько разновидностей, преобладает альмандин (1,7-7,7\%): бесцветные, розоватые, буровато-красноватые, единичные медово-желтые и зеленоватые угловато-окатанные, иногда имеют черепитчатую поверхность. По результатам рентгенофазового анализа это альмандин $\left(\mathrm{Ca}_{0.24} \mathrm{Mg}_{1.12} \mathrm{Mn}_{0.04} \mathrm{Fe}_{1.59}\right)\left(\mathrm{Al}_{1.99} \mathrm{Cr}_{0.01}\right) \mathrm{Si}_{3} \mathrm{O}_{12}$, пироп ( $\left.\mathrm{Mg}_{0.742} \mathrm{Ca}_{0.258}\right)_{3} \mathrm{Al}_{2}\left(\mathrm{SiO}_{4}\right)_{3}$, андрадит $\mathrm{Ca}_{3} \mathrm{Fe}_{2} \mathrm{Si}_{3} \mathrm{O}_{12}$, спессартин $\mathrm{Mn}_{3} \mathrm{Al}_{2} \mathrm{Si}_{3} \mathrm{O}_{12}$.

Изучение количественного и качественного анализа проб из золотосодержащих осадков пляжа показало, что, помимо золота, в значительных количествах здесь присутствуют титаномагнетит, ильменит, гранаты, которые могут быть использованы в случае выявления промышленных россыпей золота.

\section{Заключение}

Исследования на участке побережья между устьями рек Большая и Митога показали, что естественные золотоносные гранат-магнетитовые шлихи очень широко распространены на пляже в виде обогащенных слоев (до 7) малой мощности (от 1 до 10 см) как непосредственно на его поверхности, так и по разрезу. Золото присутствует в разных количествах в большинстве проб и распределено в отложениях крайне неравномерно. Там, где содержания высокие, объем пляжного материала, содержащего благородный металл, как правило, небольшой. Наиболее благоприятен для образования пляжевых россыпей мелкозернистый, равномернозернистый состав пляжевых отложений с размером зерен в основном 0,1-0,5 мм. Продуктивные участки прослеживаются с перерывами вдоль всего абразионного берега и приурочены, чаще всего, к основанию клифа, часто представленного водно-ледниковыми, «мореноподобными» образованиями. Здесь максимальные содержания золота 
в отложениях на поверхности пляжей шириной 30 м составляют $420 \mathrm{Mг} / \mathrm{M}^{3}$ (по данным [6] - 1050 мг/ м $^{3}$ ); на пляжах шириной 30-50 м - 805, 1310 мг/м³ (по данным [6] 2695 мг/м³); на пляжах шириной 50-70 м до $180 \mathrm{мг} / \mathrm{M}^{3}$. По разрезу максимальные концентрации золота встречены на глубине 0,3 м в нижней части отложений пляжей шириной 30 м - 2095 и 1525; а в пляжах шириной 30-70 м на глубине 0,5 м - 1200 мг/ $\mathrm{M}^{3}$ (по данным [6] - $3240 \mathrm{Mг} / \mathrm{M}^{3}$ ).

Таким образом, полученные нами данные и анализ проведенных в разные годы исследований свидетельствуют о том, что на абразионных участках, где клиф золотоносен, ореолы золота в отложениях пляжа постоянны. Изменяются такие параметры, как содержание металла, очертания ореолов, но места их расположения почти всегда одни и те же. Если взять протяженный отрезок берега в несколько километров, то общие запасы на нем почти не изменятся, хотя необходимо учитывать изменения гидродинамического режима в годовом и многолетнем циклах. Происходит перманентное питание пляжей, смежных с промежуточными коллекторами, в процессе абразии которых и образуются золотоносные отложения.

Изменение положения золотоносного пласта в отложениях пляжей абразионного берега (неполного профиля) зависит от их нахождения в различных морфодинамических условиях. На более узких пляжах, более литодинамически активных, он обнажается, выходя на поверхность. Там, где ширина пляжей больше, он «ныряет» под горизонт менее золотоносных отложений. На пляжах полного профиля шлиховые ореолы не имеют четких границ и несут, в первую очередь, первичную информацию о потенциальной золотоносности отложений подводного склона. Факт обнаружения повышенных концентраций золота в отложениях на смежном с пляжем участ-

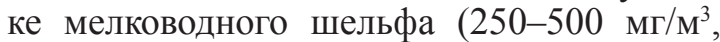
максимальные до $1168 \mathrm{мг} / \mathrm{m}^{3}$ [6]) позволяет предположить, что при последующих исследованиях на подводном береговом склоне могут быть обнаружены промышленные россыпи золота. Анализ предыдущих исследований показал, что наиболее благоприятными являются участки подводного склона, примыкающие к абразионным берегам, у подножия которых на пляже встречены золотоносные естественные шлихи.

Морфодинамические особенности процессов береговой зоны юго-западной Камчатки в целом сложны. Недостаточно из- учены их количественные характеристики, изменчивость во времени. Проведение дополнительных исследований позволит уточнить условия формирования золотоносных отложений современного пляжа, мелководной зоны шельфа и откроет новые перспективы, поскольку в мире растет интерес к прибрежно-морским россыпям (в том числе находящимся в пределах шельфа), опоискованность и разведанность которых весьма незначительны.

\section{Список литературы / References}

1. Garnett R.H.T. Marine placer gold, with particular reference to Nome, Alaska. In: Cronan D.S. (Ed.). Handbook of Marine Mineral Deposits. CRC Press, Boca Raton, Florida. 2000. P. 67-101.

2. Hou B., Keeling J., Van Gosen B.S. Geological and Exploration Models of Beach Placer Deposits, Integrated from Case-Studies of Southern Australia. Ore Geology Reviews. 2017. Vol. 80. P. 437-459. DOI: 10.1016/j.oregeorev.2016.07.016.

3. Kirkpatrick L.H., Jacob J., Green A.N. Beaches and bedrock: How geological framework controls coastal morphology and the relative grade of a Southern Namibian diamond placer deposit. Ore Geology Reviews. 2019. Vol. 107. P. 853-862. DOI: 10.1016/j.oregeorev.2019.03.029.

4. Иванова А.М., Смирнов А.Н., Пашковская Е.А. Геолого-промышленные типы россыпей в шельфовых областях Мирового океана // Тихоокеанская геология. 2004. Т. 23. № 4. C. $86-101$

Ivanova A.M., Smirnov A.N., Pashkovskaya E.A. Geological and industrial types of placers in the shelf areas of the World Ocean // Tihookeanskaya geologiya. 2004. T. 23. № 4. P. 86-101 (in Russian).

5. Лаломов А.В. Россыпи Российской Арктики и перспективы их отработки // Минералогия. 2017. № 2. С. 30-42.

Lalomov A.V. Placers of the Russian Arctic and the prospects of their mining // Mineralogiya. 2017. № 2. P. 3042 (in Russian).

6. Бондаренко И.В., Хитров В.В. Отчет Камчатской партии о результатах общепоисковых работ на россыпи шельфа южной части западного побережья Камчатки за 1976-1978 гг. В 2-х книгах. Петропавловск-Камчатский: Фонды ВГФ, ТГФ, 1979. К. 1. 140 с., К. 2.256 с.

Bondarenko I.V., Khitrov V.V. Report of the Kamchatka party on the results of general prospecting works on the placer deposits of the southern part of the western coast of Kamchatka for 1976-1978. V 2-h knigah. Petropavlovsk-Kamchatskij: Fondy VGF, TGF, 1979. K. 1. 140 p., K. 2. 256 p. (in Russian).

7. Кунгурова В.Е. К вопросу о россыпной золотоносности прибрежно-морской зоны Юго-Западной Камчатки // Руды и металлы. 2014. № 5. С. 19-31.

Kungurova V.Ye. On the question of alluvial gold mineralization of the coastal-marine zone of South-Western Kamchatka // Rudy i metally. 2014. № 5. P. 19-31 (in Russian).

8. Кунгурова В.Е. Золотоносные прибрежно-морские россыпи побережий Юго-Западной Камчатки и полуострова Аляска // Горный информационно-аналитический бюллетень. 2020. № 12 (специальный выпуск 46). С. 5-25. DOI: 10.25018/0236-1493-2020-12-46-5-25.

Kungurova V.Ye. Gold-bearing coastal marine placers the of coasts of South-Western Kamchatka and Alaska peninsula // Gornyj informacionno-analiticheskij byulleten'. 2020. № 12 (special'nyj vypusk 46). P. 5-25 (in Russian).

9. Кунгурова В.Е. Минеральный состав золотосодержащих титаномагнетитовых отложений юго-западного побережья Камчатки // Геология, география и глобальная энергия. 2018. № 4 (71). C. 79-86. DOI: 10.21672/2077-6322-2018-71-4-079-086.

Kungurova V.Ye. Mineral composition of gold-bearing titanomagnetite deposits of the south-western coast of Kamchatka // Geologiya, geografiya i global'naya energiya. 2018. № 4 (71). P. 79-86 (in Russian).

10. Manual No. ME11559A02. Cat. No. 2036E101/102/ 201/202/301/302. Theta-Theta Type X-ray Diffractomator U1tima IV. Instruction Manual. Tokyo. BOEKI LTD. 2012. 77 p. 